\title{
Installation of potable water supply and heat supply at base of subsoil water
}

\author{
Alla Evseevna Denysova ${ }^{*}$, Anton Stanislavovich Mazurenko, and Anastasiia Sergeevna Denysova \\ Odessa National Polytechnic University, Department of Thermal Power Plants and Energy Saving Technologies, Av. \\ Shevchenko 1, 65044 Odessa, Ukraine
}

\begin{abstract}
Removal of groundwater with further use of it for potable water supply and heat supply with the use of heat pump is an important problem. A new revolutionary approach to the decision of energy and water saving that provides rational accommodation of groundwater boreholes ensuring the required flow rate of water through the heat pump evaporator with simultaneously high intensity of heat exchange process is proposed. The method of calculation which allows determining the necessary depth of borehole, quantity of boreholes, in consideration of flow rate and temperature of subsoil water determining capacity of heat pump installation is worked out.
\end{abstract}

\section{Introduction}

Numerous regions of the world are under negative influence of subsoil water circulating near surface of the ground. That is why the purpose of the work is to estimate the prospects of implementation of the installation for removal of subsoil water from houses for further supply of potable water and heat to consumers at the base of heat pump [1]. This task is especially important in the autumn-winter period for regions with high level of subsoil water when danger of flooding of the buildings is grown considerably and deficiency of energy for heating increases simultaneously [2-5].

\section{A general material}

We offer new revolutionary approach to the decision of this task that provides rational accommodation of subsoil water boreholes supporting the required flow rate of water for thermal needs of heat pump evaporator with high intensity of heat exchange process simultaneously. The circuit of heat pump installation with integrated purposes (preventing flooding of buildings during a high-water period of time, heat and potable water supply) at base of subsoil water includes a borehole circuit and water purification circuit. Heat pump installation of potable water and heat supply at base of subsoil water has a special module for water purification [6].

\footnotetext{
* e-mail: alladenysova@gmail.com
}

Installation of potable water and heat supply (Fig. 1) at base of heat pump 3 includes the evaporator 5 , compressor 6 , condenser 7 and throttle gate 8 . Evaporator 5 is placed in the circuit of circulation of subsoil water incoming from borehole 1 via pump 2. Condenser is placed in the circuit of circulation of heat consumer 10 . The system of water purification 4 includes subsoil water tank 11, incoming through evaporator 5, water pump 12, module of purification with tanks 13, 14 and pump 15 for potable water supply of consumers 16 .

\section{Research method}

Flow rate of subsoil water [6]:

$$
V_{w}=\frac{\pi \times\left(H_{0}^{2}-h_{0}^{2}\right) \times k}{\ln \left(R / r_{0}\right)} \mathrm{m}^{3} / \mathrm{s}
$$

where $R=3000 \times\left(H_{0}-h_{0}\right) \times k^{-2}$-radius of funnel, $\mathrm{m}$; $k=10^{-5}, 0.5 \times 10^{-5}, 10^{-6}$ - filtration coefficient for sand, loam and clay accordingly, $\mathrm{m} / \mathrm{s} ; \quad r_{0}=0.075, \quad 0.15$, 0.3 -radius of borehole, $\mathrm{m}[7]$.

Heat power of the heat pump at subsoil water which is defined as [8]:

$$
Q_{0}=G_{w} \times C_{p} \times \Delta t,
$$

where $G_{B}=V_{w} \times \rho_{w}, \mathrm{~kg} / \mathrm{s} ; \rho_{w}$-density, $\mathrm{kg} / \mathrm{m}^{3} ; \mathrm{C}_{\mathrm{p}}-$ specific heat capacity, $\mathrm{kJ} /(\mathrm{kg} \mathrm{K}) ; \Delta \mathrm{t}$ - cooling of water in evaporator $\left(\Delta t_{w}=t_{w}^{v x}-t_{w}^{v u x}=14-4=10 \mathrm{~K}\right) ; t_{w}^{v x}, t_{w}^{v u x}$-inlet and outlet temperature of water in evaporator. 


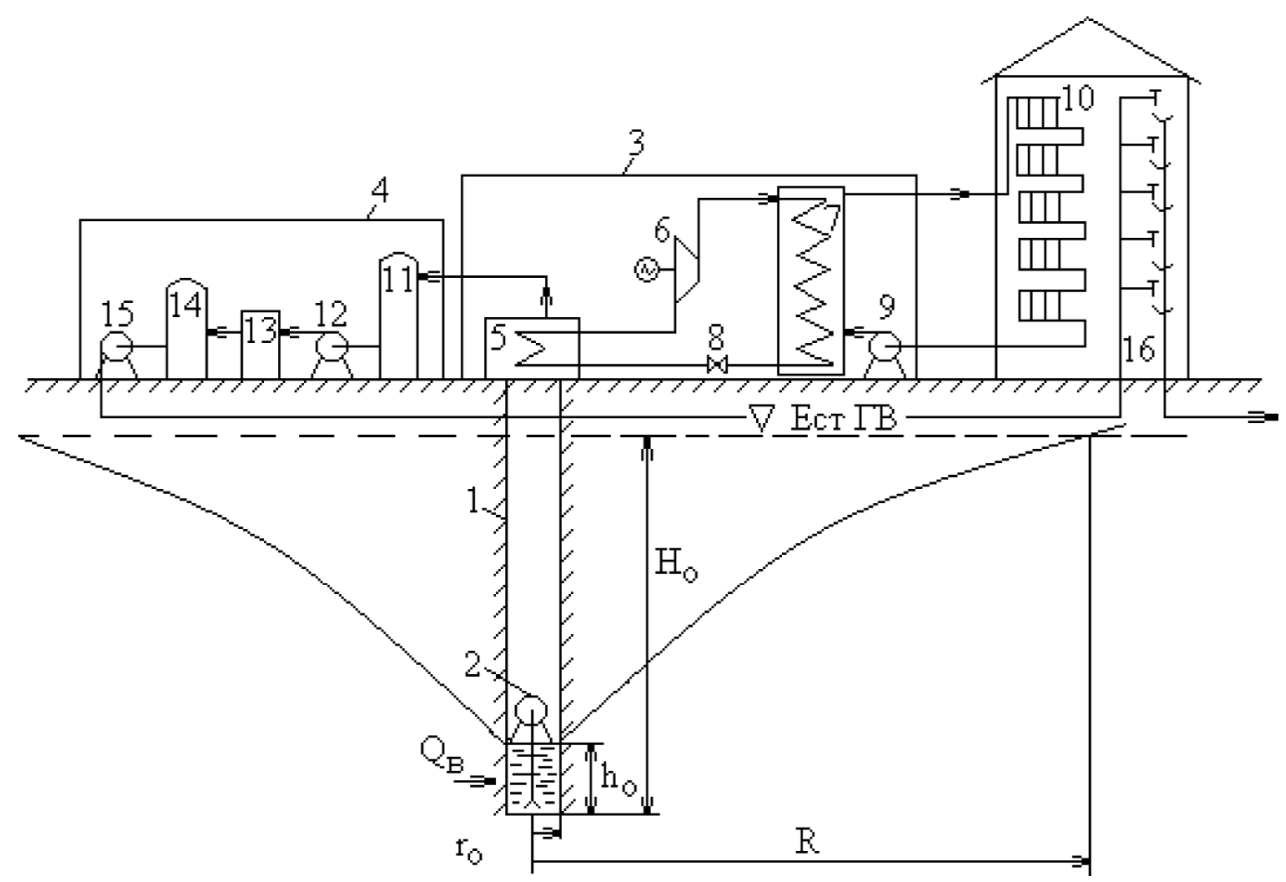

Fig. 1. Installation of potable water and heat supply at base of subsoil water. 1 - borehole; 2, 9, 12, 15-pump; 3-heat pump; 4 - module of water purification; 5-evaporator; 6-compressor; 7 -condenser; 8 -throttle gate; 10 -heat consumer; 11-subsoil water tank; 13 -tank for water purification; 14 -tank with potable water; 16 - potable water consumer.

\section{Results and discussion}

Results of numerical simulation (Figs. 2 and 3) shows that flow rate of subsoil water is close to square-law dependence on pressure $z=H_{0}-h_{0}$, because of laminar mode of flow of subsoil water through the ground layer. Flow rate of subsoil water depends proportionally on filtration factor $f$ but influence of borehole's radius $r_{0}$ is negligible. Figure 2 allows determining necessary depth of borehole $\mathrm{H}_{0}$ with the account of $h_{0}$ and quantity of boreholes (at changes of borehole depth).

For heat pump evaporator having surface area of heat transfer $F=320 \mathrm{~m}^{2}$, having heat transfer coefficient $k_{f}=0.5 \mathrm{kWh} /\left(\mathrm{m}^{2} \mathrm{~K}\right)$ for temperature difference $\Delta t=6{ }^{\circ} \mathrm{C}$, which corresponds to the heat flow density $q=3 \mathrm{~kW} / \mathrm{m}^{2}$.

The heat power (Fig. 3) of the evaporator can be defined as: $Q_{0}=q \times F=3 \times 320=960 \mathrm{~kW}$.

For the case of cooling of subsoil water in the evaporator of heat pump $\Delta t_{w}=10^{\circ} \mathrm{C}$ the required flow rate of subsoil water, with the account of equation (2), can be defined as:

$$
G_{w}=\frac{Q_{0}}{C_{p} \times \Delta t}=\frac{960}{4.2 \times 10}=22.8 \mathrm{~kg} / \mathrm{s} .
$$

The temperature of the refrigerant boiling in the evaporator of heat pump can be estimated as [9]:

$$
E=\frac{C_{w}\left(t_{w}^{v x}-t_{w}^{v u x}\right)}{C_{\min }\left(t_{w}^{v x}-t_{0}\right)}
$$

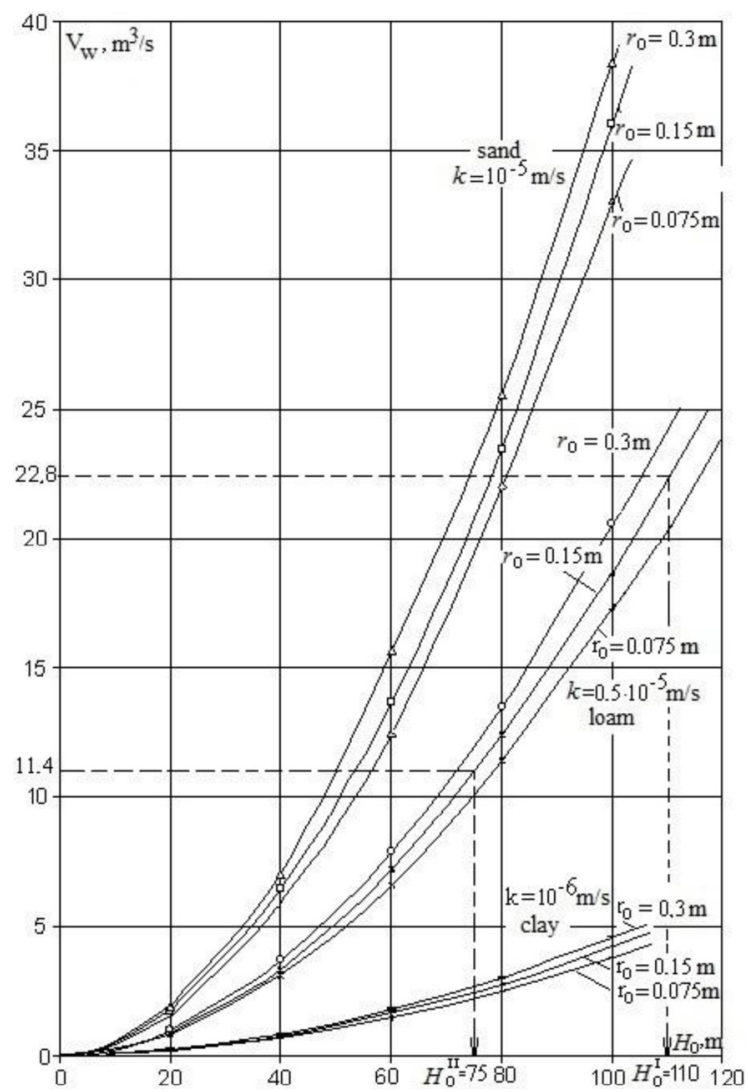

Fig. 2. Flow rate and depth of borehole. 


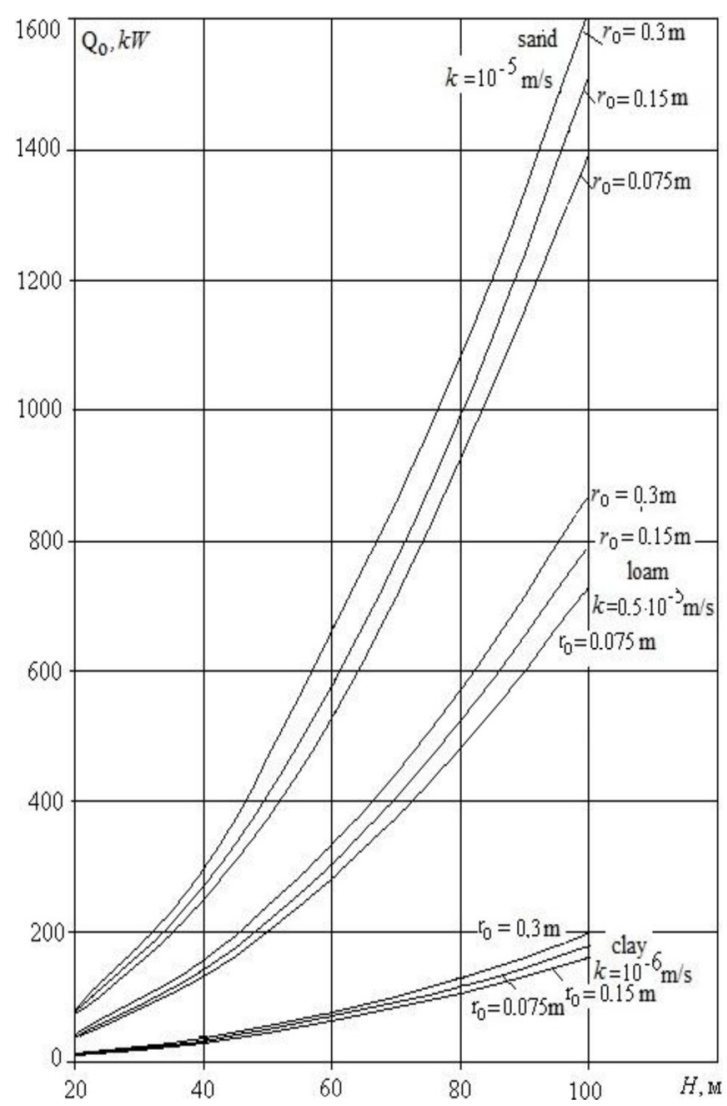

Fig. 3. Heat power of the evaporator. where $E$-thermodynamic efficiency, which show the ratio of real flow of heat to maximum possible in the ideal heat exchanger.

In our case $C_{w}=C_{\min }$, therefore:

$$
E=\frac{t_{w}^{v x}-t_{w}^{v u x}}{t_{w}^{v x}-t_{0}} .
$$

From equation (4):

$$
t_{0}=t_{w}^{v x}-\frac{t_{w}^{v x}-t_{w}^{v u x}}{E},
$$

where $E=1-\exp \left[-k_{f} \times F /\left(C_{p} \times G_{w}\right)\right]$-for evaporator of the heat pump [10].

In order to estimate the cost-effectiveness of the installation the method of economic evaluation based on a comparison of cost of the traditional heat supply unit and traditional water supply unit was applied [11-13] .

Results of numerical simulation shows that in case of three boreholes (for example, for loam) when the depth of each borehole is $60 \mathrm{~m}$ the flow rate of subsoil water equals $G_{w}=7.6 \times 3=22.8 \mathrm{~kg} / \mathrm{s}$ (Fig. 2). Temperature of boiling of refrigerant (R-142) equals $1.5^{\circ} \mathrm{C}$; temperature of condensation of refrigerant equals $70^{\circ} \mathrm{C}$; temperature of hot water $65{ }^{\circ} \mathrm{C}$; efficiency of compressor 0.85 ; flow rate of refrigerant equals $7.3 \mathrm{~kg} / \mathrm{s} ; \mathrm{COP}=3.5$; heat capacity of condenser of heat pump equals $1350 \mathrm{~kW}$; electric capacity of electric motor for compressor equals $N_{K}=390 \mathrm{~kW}$; heat capacity of heat pump evaporator equals $960 \mathrm{~kW}$, capacity of 3 electric motors for subsoil water pump equals $16 \mathrm{~kW}$. While heat capacity of heat pump equals $Q_{h}=1350 \mathrm{~kW}$, the quantity of apartments which can be supplied by heat equals 450 (needs of one apartment approximately $3 \mathrm{~kW}$ [14].

The total economic efficiency of heat and water supply system can be determine with the account of annual costs of heat supply system $Z_{h}^{y}$ and water supply system $Z_{w}^{y}$ (e.g. $G_{w}=22.8 \mathrm{~kg} / \mathrm{s}$ ) [13]:

$$
\begin{aligned}
& Z_{h}^{y}=C_{h}^{y} K_{h} \times E_{n}, \\
& Z_{w}^{y}=C_{w}^{y} K_{w} \times E_{n},
\end{aligned}
$$

where $C_{h}^{y}, C_{w}^{y}$-annual operating costs of heat and tap water production; $K_{h}, K_{w}$-costs of the system (including costs of heat pump, boreholes with water pumps and water supply system with water treatment installation); $\mathrm{E}_{n}$-normative amortization factor $\left(\mathrm{E}_{n}=0.1\right)$.

Annual operating costs for the generation of heat:

$$
\begin{aligned}
C_{h}^{y} & =C_{e l}^{h} \times N_{e l}^{h} \times \tau_{y} 12 \times n \times Z_{n} \\
& =0.02 \times 420 \times 876012 \times 5 \times 200 \\
& =74,800 \mathrm{USD} / \text { year },
\end{aligned}
$$

where $C_{e l}^{h}$ - cost of $1 \mathrm{kWh} ; \tau_{y}=8760-$ annual operating hours; $n$-number of persons serving the installation; $Z_{n}$-monthly salary per person; $N_{e l}^{h}$-electric power for generation of heat.

$$
N_{e l}^{h}=N_{k} N_{e l}=39030=420 \mathrm{~kW},
$$

where $N_{k}$-electric capacity of electric motor of compressor; $N_{e l}$-electric power of water pump.

Annual costs for heat generation:

$$
\begin{aligned}
Z_{h}^{y} & =C_{h}^{y} K_{h} \times E_{n}=74,8005 \times 10^{5} \times 0.1 \\
& =125 \times 10^{3} \mathrm{USD} / \text { year. }
\end{aligned}
$$

Specific costs for heat production:

$$
\begin{aligned}
z_{h}^{s p} & =\frac{Z_{h}^{y}}{Q_{h}^{y}}=\frac{125 \times 10^{3}}{1350 \times 8760}=1.05 \times 10^{-2} \mathrm{USD} / \mathrm{kWh} \\
& =3 \mathrm{USD} / \mathrm{GJ} .
\end{aligned}
$$

Annual operating costs for the generation of pure water:

$$
\begin{aligned}
C_{w}^{y} & =C_{e l}^{w} \times N_{e l}^{w} \times \tau_{y} 12 \times n \times Z_{n} \\
& =0.02 \times 30 \times 876012 \times 5 \times 200 \\
& =17,250 \mathrm{USD} / \text { year }
\end{aligned}
$$

where $N_{e l}^{w}=30 \mathrm{~kW}$-electric power for pumps of water treatment unit.

Annual costs for water supply system:

$$
Z_{w}^{y}=C_{w}^{y} K_{w} \times E_{n}=17,2500.1 \times 10^{5}=272.5 \times 10^{3} .
$$


Specific costs for water provision in case of three boreholes:

$$
\begin{aligned}
z_{w}^{s p} & =\frac{Z_{w}^{y}}{Q_{w}^{y}}=\frac{Z_{w}^{y}}{G_{w} \times \tau_{y}}=\frac{272.5 \times 10^{3}}{22.8 \times 3.6 \times 8760} \\
& =0.038 \mathrm{USD} / \mathrm{m}^{3} .
\end{aligned}
$$

Annual cost savings for heat supply system based on our proposals:

$$
\begin{aligned}
\Delta z_{h}^{y} & =\left(z_{h s}^{s p}-z_{h}^{s p}\right) \times Q_{h} \times \tau_{y} \\
& =(5-3) \times 1350 \times 3.6 \times 8760 \\
& =81 \times 10^{3} \mathrm{USD} / \text { year. }
\end{aligned}
$$

where $z_{h s}^{s p}=5 \mathrm{USD} / \mathrm{MJ}$ - costs of heat incoming from boiler.

Annual cost savings for water provision based on our proposals:

$$
\begin{aligned}
\Delta z_{w}^{y} & =\left(z_{w s}^{s p}-z_{w}^{s p}\right) \times Q_{h} \times \tau_{y} \\
& =(0.1-0.038) \times 22.8 \times 3.6 \times 8760 \\
& =45 \times 10^{3} \mathrm{USD} / \text { year },
\end{aligned}
$$

where $z_{w s}^{s p}=0.1 \mathrm{USD} / \mathrm{m}^{3}-$ costs of pure water.

Cost savings due to implementation of water provision system while $T=10$ years of operation:

$$
\Delta z_{w}=\Delta z_{w}^{y} \times T=45 \times 10^{3} \times 10=450 \times 10^{3} \mathrm{USD} .
$$

Cost savings due to implementation of heat provision system while $T=10$ years of operation:

$$
\Delta z_{h}=\Delta z_{h}^{y} \times T=81 \times 10^{3} \times 10=810 \times 10^{3} \text { USD } .
$$

General cost savings due to implementation of installation of heat and potable water supply at base of heat pump while $T=10$ years of its operation can be defined as:

$$
\Delta z=\Delta z_{h} \Delta z_{w}=810 \times 10^{3} 450 \times 10^{3}=1.26 \times 10^{6} \mathrm{USD} .
$$

\section{Conclusions}

Removal of subsoil waters from the surface of the ground with its subsequent use for water and heat supply reduces negative influence of subsoil waters circulating near to surface of the ground. Especially during autumn-winter period in the regions with high level of subsoil water a danger of flooding of the buildings becomes real and deficiency of energy for heating rises simultaneously. Heat pump installation with integrated purposes-water and heat supply - can compensate escalating annually deficiency of potable water for numerous regions having problems with water deficit and allows solving the problem of substitution of traditional fuels.

Social effect of implementation of heat pump installation with integrated modes of work - preventing flooding of buildings during a high water period.
The results of numerical simulations show technical and economic expediency of application of heat pump installation with integrated purposes. The general economy while 10 years equals $1.26 \times 10^{6} \mathrm{USD}$ (including water provision$0.45 \times 10^{6} \mathrm{USD}$, heating $\left.0.81 \times 10^{6} \mathrm{USD}\right)$.

The amount of specific investments into heat pump systems is largely determined by the applied technology and quantity of heat and water derived from the utilization of subsoil water. In general, the specific costs decrease with an increase in integrated capacity of system.

\section{References}

1. A.E. Denysova, A.S. Mazurenko, Utilization of ground heat in a heat pump combined solar-ground heat supply systems, in Proc. of ISES Solar World Congress, Jerusalem (1999), p. 77

2. P.F. Healy, V.I. Ugursal, Performance and economic feasibility of ground source heat pumps in cold climate, J. Energy Res. 21, 857 (1997)

3. V. Badescu, Economic aspects of using ground thermal energy for passive house heating, J. Renew. Energy 32, 895 (2007)

4. D. Marcotte, P. Pasquier, F. Sheriff, M. Bernier, The importance of axial effects for borehole design of geothermal heat-pump systems, J. Renew. Energy 35, 763 (2010)

5. A.E. Denysova, A.S. Mazurenko, Integrated alternate system of thermal consumption, in Proc. of 15th Int. Conference World Sustainable Energy Days, Wels, Austria (2006), Vol. 1, p. 275

6. A.E. Denysova, A.S. Mazurenko, Installation of potable water supply and heat supply on base of subsoil waters for sustainable technologies, in Proc. World Sustainable Energy Days, Wels, Austria (2006), Vol. 1, p. 119

7. A.E. Denysova, A.S. Mazurenko, A.V. Kaminski, Use of subsoil water for heat and water supply, J. Environ. Technol. Resour. Saving 4, 3 (2006)

8. A.E. Denysova, A.S. Mazurenko, The influence of accuracy accounting of heat on thermal efficiency of heat supply unit, in Proc. of 15th Int. Conference Commercial Accounting of Heat Carriers and Improvement of the Flow Measurement of Liquid, Gas and Steam, Saint-Petersburg (2002), Vol. 1, p. 363

9. J. Bosma, Heat Pumps for Energy Efficiency and Environmental Progress (Elsevier Science Publishers, Amsterdam, 1993), p. 596

10. F. Kreith, W. Black, Basic Heat Transfer (Harper and Row, New York, 1980), p. 521

11. M. Kaltschmitt, W. Streicher, A. Wiese, Renewable Energy: Technology, Economics and Environment (Springer, Berlin, 2007), p. 564

12. A.E. Denysova, A.N. Troitskiy, Efficiency of heat pump of heat supply system, in Proc. of 11th International Conference Power Engineering GRE, J. Opole Technical University (2008), Vol. 60, p. 79

13. A.E. Denysova, A.S. Mazurenko, Heat pump unit for heat and water supply at base of renewable energy, in Proc. of International Conference Energy Efficiency of Odessa and Ifs Future, Odessa, 21 February (2008), Vol. 1, p. 265

14. W.M. Kays, A.L. London, Compact Heat Exchangers (McGraw-Hill, New York, 1984), p. 157

Cite this article as: Alla Evseevna Denysova, Anton Stanislavovich Mazurenko, Anastasiia Sergeevna Denysova, Installation of potable water supply and heat supply at base of subsoil water, Renew. Energy Environ. Sustain. 1, 43 (2016) 